\title{
Sources of open innovation in foreign subsidiaries: An enriched typology
}

\author{
Filip De Beule ${ }^{a, *}$, Ilke Van Beveren ${ }^{\mathrm{b}}$

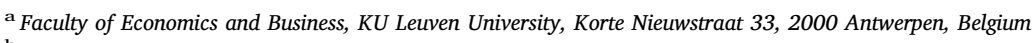 \\ ${ }^{\mathrm{b}}$ Faculty of Economics and Business, KU Leuven University, Belgium
}

A R T I C L E I N F O

\section{JEL classification:}

F23

L23

O31

O33

Keywords:

Technology exploiting

Technology exploring

R\&D intensity

Multinational subsidiaries

Open innovation

Knowledge sources

\begin{abstract}
A B S T R A C T
This paper analyzes the drivers of multinational affiliates' innovation, using a dataset based on the Community Innovation Survey for Belgium. Specifically, we investigate the role of external knowledge sources on foreign affiliates' research efforts and innovation. We thereby develop an enriched typology by taking both the MNC and the host country perspective into consideration and distinguish between different types of subsidiaries, in order to disentangle differences in the use of knowledge sources between technology exploiting, seeking and creating subsidiaries. Our findings show that technology-creating foreign affiliates are able to tap into a combination of industry-based value chain partners and science-based partners. In particular, a combination of clients and universities have a powerful impetus on the research effort of technology creating firms. Our results also indicate that technology-seeking subsidiaries make more use of collaboration with competitors. Technology exploiting subsidiaries make significantly less use of external knowledge sources and have a lower R\&D intensity.
\end{abstract}

\section{Introduction}

In recent years, a good deal of literature has been devoted to the motive of knowledge seeking in the international activities of multinational companies (MNCs) (e.g., Cantwell, 1989; Cantwell \& Mudambi, 2011; Cantwell \& Piscitello, 2000; Kappen, 2011; Liu, Vahtera, Wang, Wang, \& Wei, 2017; Michailova \& Zhan, 2015). The increasing internationalization of R\&D by MNCs is reflected in the growing role played by foreign affiliates in the R\&D activities of many countries (Narula \& Zanfei, 2005; UNCTAD, 2005). This growing evidence of a "globalization of innovation" trend means that foreign subsidiaries are increasingly carrying out R\&D themselves. The R\&D resources of a foreign subsidiary can play two roles: facilitate local adaptation of the MNC's products and services or enable the creation and acquisition of globally relevant technology for the entire corporation (Feinberg \& Gupta, 2004; Makino, Lau, \& Yeh, 2002; Zhang, Jiang, \& Cantwell, 2015).

The purely internal view of innovation has been increasingly fading as recent literature has highlighted the merits of acquiring external knowledge and moved away from intramural research and development to open innovation (Cruz-González, López-Sáez, \& Navas-López, 2015; Grimpe \& Sofka, 2009; Huston \& Sakkab, 2006). To cope with the increased complexity of innovation, research collaboration provides access to resources firms cannot generate internally. This allows firms to develop valuable knowledge assets through a joint effort with partner firms (Knudsen, Tranekjer, \& Cantner, 2017). The role of learning from external sources as a key means for obtaining new valuable ideas for the innovative process has therefore gained much attention. The concept of open innovation was coined by Chesbrough (2003) to explain and understand the various combinations of knowledge sourcing strategies. The open innovation model relies on the notion that a single organization cannot successfully innovate in isolation (Dahlander \& Gann, 2010). External knowledge acquisition becomes critical since it complements and renews knowledge stocks available within the organization.

Open innovation has contributed to the proliferation of empirical studies which investigate how knowledge collaboration with different external sources can affect firms' innovation (Berghman, Matthyssens, \& Vandenbempt, 2012; Chen, Lin, \& Chang, 2009; Chen, Chen, \& Vanhaverbeke, 2011; Chesbrough, 2003; De Luca \& Atuahene-Gima, 2007; Laursen \& Salter, 2006; Zhang, Hoenig, Di Benedetto, Lancioni, \& Phatak, 2009). This research stream has devoted considerable efforts to identify those external sources having a bigger effect on firm's innovativeness and ability to develop more novel products (CruzGonzález et al., 2015). However, these studies offer mixed results and do not enable reaching a clear conclusion about which external knowledge sources are more relevant in order to reach different innovation outputs.

\footnotetext{
* Corresponding author.

E-mail address: Filip.DeBeule@kuleuven.be (F. De Beule).
} 
Existing empirical quantitative contributions scarcely address the fact that not all sources may be of equal value for innovating firms. Thus, the nature of external knowledge sourcing presents a critical but poorly explored and understood aspect of open innovation (Brunswicker \& Vanhaverbeke, 2015). This is even more so the case for foreign subsidiaries. The main objective of this paper is therefore to analyze and determine the firm-level drivers of innovation of foreign subsidiaries. It will analyze to what extent foreign affiliates' research activities are shaped by its access to and use of local knowledge sources. We will specifically investigate whether foreign affiliates are able to innovate by tapping into local knowledge sources. In particular, we will make a distinction on the basis of industry-based and science-based external partners. As to foreign subsidiaries' innovation, our study focuses on product innovation and distinguishes by the degree of novelty to the firm, on the one hand, and novelty to the market, on the other hand. We believe our typology based on firms' existing knowledge as well as on prior knowledge being present in the host market concerning the innovation that is introduced, will yield novel insights into the determinants of foreign subsidiaries' type of innovation.

We would like to suggest that the usefulness of different industrybased and science-based partners on research and innovation is dependent on an important boundary condition, i.e., the type of subsidiary innovation. It is suggested here that we have to take account of the type of subsidiary innovation in order to explain the usefulness of the different knowledge sources in foreign subsidiaries' innovation. We would therefore like to find out what type of knowledge source has an important yet divergent impact on foreign subsidiaries.

This study has a number of contributions. First, our enriched typology of different technology exploiting and technology exploring strategies move away from a purely MNC-driven approach and contributes to IB literature by offering a more fine-grained lens to understand MNCs and their technology exploiting and exploring subsidiaries. Second, this study intends to contribute to the extant literature on open innovation by taking science-based and industry-based partnerships simultaneously into account, and by examining how innovation strategies with different types of external partners feed into the innovation of different types of subsidiary companies. Third, the processes we outline carry important consequences for the locations that host the subsidiaries as well, making this issue of interest to policy makers. Our insights into the determinants of foreign affiliates' innovativeness might allow host countries to create an environment conducive to foreign innovation efforts, allowing them to attract more research activities while MNCs can contribute to transforming the location itself.

Finally, important insights into the linkages from the local environment towards multinational subsidiaries can inform multinational (subsidiary) managers of how to benefit from their local presence. In a world of increasing global knowledge flows, innovation management is increasingly challenged to access and relate to the right knowledge sources to ensure innovation. Collaborating with appropriate partners that possess heterogeneous and tacit knowledge are truly challenging tasks for even the most experienced innovation managers (Knudsen et al., 2017).

The rest of this paper is organized as follows. Section 2 discusses background literature and puts forward our conceptual model and related hypotheses, while Section 3 describes the data set and relevant summary statistics. Section 4 deals with the empirical analysis and Section 5 discusses the major results of our analyses and draws relevant conclusions for managers and policy makers.

\section{Literature}

\subsection{Literature background}

Innovative effort is traditionally expected to take place mainly in the home country of multinational corporations (Castellani \& Zanfei, 2006), whereby the MNC exploits its existing knowledge through a network of subsidiaries. However, MNCs are increasingly seeking complementary foreign assets and knowledge-facilitating capabilities in order to add value to their core competitive advantages. Examples of this approach indicate that foreign-owned subsidiaries typically tap into local industry in order to keep their parent company informed about leading-edge thinking (Bartlett \& Ghoshal, 1986; Ghoshal \& Bartlett, 1988; Patel \& Vega, 1999), while studies by Frost (2001) and Almeida and Kogut (1997) show how subsidiaries draw from local sources in their innovation processes. Cantwell (1989) argued that in order to benefit from knowledge feedbacks, MNCs' subsidiaries have to internalize foreign technology development, which implies that their own operations have to be firmly embedded in the host-country environment. Frost (2001) makes a similar argument, which he also formulates from an embeddedness perspective. His empirical analysis of patent citations made by a sample of US-based subsidiaries of foreign MNCs during the period 1980-1990 provides broad empirical support for this reasoning.

So literature has typically made a distinction between value creation that rests on the adaptation and deepening of the established competencies of the MNC group and value creation that extends MNC group competencies into new areas, usually by combining MNC group knowledge with knowledge from fields of expertise previously unfamiliar to the group. The first strategy has been labeled as technology, home-base, asset or competence exploiting. These strategies are associated with a view of multinational enterprises as a means to exploit firm-specific advantages in foreign markets (Barba Navaretti \& Venables, 2004; Dunning, 2000). These subsidiaries support the exploitation by adapting technologies, products and processes to local needs, consumer tastes, regulation, etc. (Dachs \& Ebersberger, 2009).

Owing to changes in the competitive, international and technological environment, MNCs have complemented this adaptive R\&D with more innovative R\&D abroad. Such a strategy has been described as technology exploring, home-base augmenting, asset or competence creating. These strategies are driven by supply factors, such as the availability of skilled researchers, the need to monitor the technological activities of competitors, clients, universities and other research organizations to assimilate local knowledge in the host countries (Castellani \& Zanfei, 2006; March, 1991; Zhang et al., 2015).

\subsection{Enriched conceptual framework}

Many authors have investigated the characteristics of companies involved in technology exploiting versus technology exploring foreign investment activities (Berry, Shankar, Parish, Cadwallader, \& Dotzel, 2006; Cantwell \& Mudambi, 2005; Kuemmerle, 1999; Le Bas \& Sierra, 2002). An important concern in this literature is how to distinguish between different motivations for FDI in R\&D and innovation. A number of studies have specifically investigated this issue, using different taxonomies to classify the motives for FDI (e.g., Cantwell \& Mudambi, 2011; Cantwell \& Smeets, 2013; Driffield \& Love, 2007; Griffith, Harrison, \& Van Reenen, 2006; Le Bas \& Sierra, 2002; Schmid \& Schurig, 2003). However, often their tests are at the macro-level, inferring firm-level strategies from country-level characteristics, while the mechanisms of knowledge appropriation and flows are at the microlevel. Besides, the field in general would benefit from a tighter match between the theoretical and empirical levels of analysis (Alcacer \& Chung, 2011).

In order to address this issue, this study divides subsidiary competence exploiting and competence exploring activities into four categories by taking both the MNC and the host country into consideration. Particularly, if innovations carried out by the subsidiary are not new to the firm, this implies that the firm is exploiting its existing ownership advantages in new locations (technology exploiting FDI from the point of view of the MNC). On the other hand, if the innovation introduced by the subsidiary is new to the firm, we consider the investment to be technology exploring FDI (from the point of view of the MNC). 


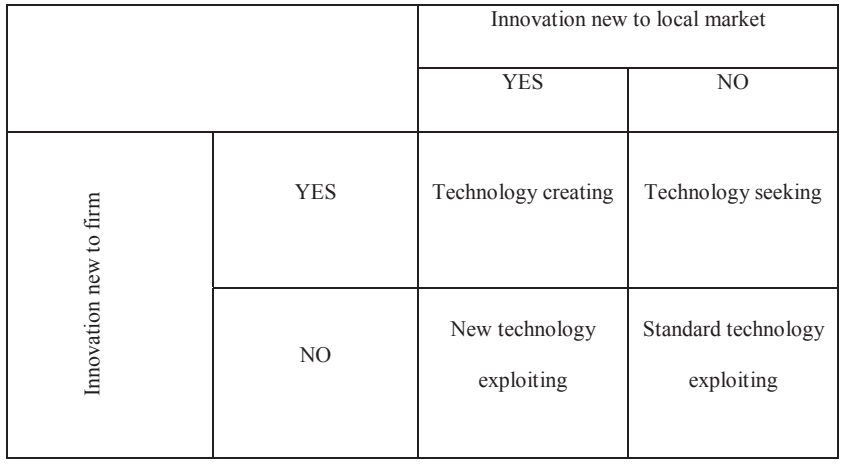

Fig. 1. Subsidiary innovation typology.

The distinction between technology exploiting versus technology exploring FDI is also relevant from a host country perspective. From a host country point of view, technology exploiting subsidiaries bring along technologies that are new to the market (although not always), while technology exploring subsidiaries attempt to learn from existing host country technologies. Knowledge seeking can indeed occur among technical laggards trying to reduce their gap by investing abroad to acquire needed knowledge. However, firms from leading technical centers will go to other leading technical centers not to catch up but to increase their knowledge diversity (Chung \& Alcácer, 2002). As such, using additional information on whether a particular innovation carried out at subsidiaries is new to the market or not, we are further able to distinguish between innovations aimed at new or existing markets. By combining information from the "new to the market" and "new to the firm" dummies, we classify subsidiaries into four different types, illustrated in Fig. 1.

Foreign subsidiaries that have introduced a product innovation that is not new to the market and not new to the firm are considered as "standard technology exploiting." If the innovation is new to the market, but not new to the firm, the subsidiary is considered to be "new technology exploiting". Similarly, if the innovation is new to the firm, we distinguish between "technology seeking firms" (innovation is new to the firm but not new to the market) and "technology creating firms" (innovation is new to the firm and the market). Technology creating subsidiaries accomplish both as they realize technological progress that is both new to the firm and new to the market.

\subsection{External knowledge sources and type of subsidiary innovation}

An increasing number of firms are tapping into different sources of external knowledge to assimilate information and technology, leverage external expertise, and adapt to dynamic environments (Chen, Vanhaverbeke, \& Du, 2016; Greco, Grimaldi, \& Cricelli, 2016; Rigby \& Zook, 2002). Prior literature has identified two major types of them: science-based (e.g., universities, public and private research institutions) and industry-based knowledge sources (e.g., customers, competitors and suppliers) (Lasagni, 2012). The use of these knowledge sources complements firms' own internal innovation activities and, given their diversity, may represent complementary types of knowledge for innovating companies (Tether \& Tajar, 2008). Since inter-firm sources offer significant amount of new knowledge to a firm, extant literature has focused on the exploration of knowledge across organizational boundaries (Beckman, Haunschild, \& Phillips, 2004; Fang, Lee, \& Schilling, 2010; Lee \& Huang, 2012; Zhang et al., 2015).

There are various reasons to collaborate with industry-based partners (Du, Leten, \& Vanhaverbeke, 2014). By working together with these value chain companies, firms can simultaneously accelerate their capability development and reduce technological innovation time and risk. These competencies and advantages could, in principle, relate to any portion of the value chain (Cantwell \& Mudambi, 2011).
Firms may source market knowledge as well as technological knowledge from industry-based partners such as users, customers, suppliers, or competitors in order to learn about market trends and technological needs (Chen et al., 2016; Du et al., 2014; Franke \& Schreier, 2002; Von Hippel \& Katz, 2002). These external knowledge sources enable firms to come up with the most promising prototypes for further development, to acquire new technological skills, to closely observe the latest market trends, and to expand their innovation networks (Chen et al., 2016; Lettl, Herstatt, \& Gemuenden, 2006). Moreover, as these value chain partners all share benefits generated from the same resulting innovation, they will actively contribute to a better innovation performance. A firm can therefore improve its technological innovation by collaborating with different types of industrial partners.

Scientific research conducted at universities and knowledge institutes is an important input for innovation rather than adaptation or imitation (Du et al., 2014). By collaborating with science-based partners, R\&D project teams gain access to tacit scientific knowledge enabling them to quickly build on the latest research findings (Fabrizio, 2009). Science based partnerships are increasingly seen as an inexpensive and low risk source of specialist knowledge (Tether, 2002). Science-based partnerships have been growing in scale and scope over time, partially stimulated by government policies to promote public private research partnerships (Leten, Vanhaverbeke, Roijakkers, Clerix, \& Van Helleputte, 2013; Perkmann \& Walsh, 2007). Firms rely on science-based partnerships to experiment with new technologies, as well as to refine existing technologies.

Science-based knowledge sources such as universities and research institutes develop and disseminate cutting-edge scientific knowledge, and provide firms with better understanding of the underlying mechanisms of fundamental and basic knowledge (Chen et al., 2016). For firms, science-based partners are an important external source to build up their knowledge base and to improve their understanding of new scientific developments (Belderbos, Carree, Diederen, Lokshin, \& Veugelers, 2004; Veugelers \& Cassiman, 2004). Universities and public research institutes may also help to provide solutions to technological problems that firms may be facing. Universities' mission of knowledge dissemination pose few concerns of knowledge leakage and appropriation (Cassiman \& Veugelers, 2002). Science-based partners may therefore facilitate knowledge flows and, as a result, contribute to better innovation of collaborating firms.

\subsubsection{Standard technology exploiting subsidiaries}

Standard technology exploiting subsidiaries introduce products that are neither new to the firm nor to the market. Therefore, these type of subsidiaries typically receive their existing multinational group's technology and products and exploit them in local markets. This concentration of strategic innovative activities in the home country allows for an intensified specialization and division of labor in innovation and the utilization of scale economies, and avoids additional costs of transmitting knowledge to and from the local subsidiary. These firms do not require local collaboration given that external sourcing leads to a greater extent of operation complexity and result in increased coordination, communication, and monitoring challenges (Hsu, Lien, \& Chen, 2015).

As such, these types of subsidiaries are less likely to make use of industry-based as well as science-based external knowledge sources. Standard knowledge exploiting subsidiaries rely mostly on existing MNC-level technology, and they do not require extensive industry- or science-based partnerships.

Hypothesis 1. Standard technology exploiting subsidiaries use less industry-based and less science-based external knowledge collaboration than other types of subsidiaries.

\subsubsection{New technology exploiting subsidiaries}

For new technology exploiting subsidiaries, adaptation to the 
market requirements might be necessary. In this sense, customers are considered a valuable source of information about markets trends, which may lead firms to anticipate opportunities (Tether, 2002). Collaborating with customers is an important way for a firm to improve its product innovation (Brockhoff, 2003; Gupta, Wilemon, \& AtuaheneGima, 2000). Working with customers not only helps to identify technology development market opportunities, but also reduces the likelihood of poor design in the early stages of development. Capturing influential customers' needs may also help firms to realize new solution ideas (Von Hippel \& Katz, 2002), quickly identify market trends, and enhance new technology applications. Understanding the customer also greatly affects new product success or failure (Li \& Calantone, 1998; Moorman, 1995; Sethi, Smith, \& Park, 2001).

Along with customers, suppliers are part of the firm's supply chain but due to their upstream position in the value chain, they incorporate more technological than market knowledge (Tsai \& Hsieh, 2009). Suppliers have expertise and knowledge on the latest technologies and components that are available on the market. Partnerships with suppliers also enable R\&D teams to identify potential technical problems early in the process (Kessler \& Chakrabarti, 1996), and therefore improve product reliability and performance.

Suppliers also have greater expertise and better knowledge of components and parts that are critical to a firm's technological development. Their expertise and different perspectives may make it easier for a firm to create new product development methods and to identify potential technical problems and increasingly difficult and costly design changes (Kessler \& Chakrabarti, 1996; Tsai \& Wang, 2009; Tsai, 2009).

Hypothesis 2. New technology exploiting subsidiaries use more industry-based (in particular suppliers and clients) external knowledge collaboration than other types of subsidiaries.

\subsubsection{Technology seeking subsidiaries}

Technological knowledge can also refer to the firm's knowledge about its competitors (De Luca \& Atuahene-Gima, 2007). Some authors have underlined the relevance of competitors as providers of complementary technological knowledge (Tödtling, Lehner, \& Kaufmann, 2009). Intra-industry information from competitors is important for firms that want to imitate existing product technologies. Köhler, Laredo, and Rammer, (2012) found that market-driven search is stronger associated with product imitation success than with new product innovation success.

It is found that competitors collaborate when they face common technological problems or to set technological standards (Tether, 2002). Competitors often stimulate each other's innovations, and they may serve as attractive partners to exploit complementary R\&D resources, to develop similar products, and to reduce costs and risks (Miotti \& Sachwald, 2003). Horizontal flows of external knowledge among competitors within the same product markets would favor mainly the recombinant generation of product innovation (Antonelli \& Fassio, 2016).

Firms can indeed improve their technological innovation by collaborating with competent competitors (Tether, 2002). By sharing technological knowledge and skills, firms involved in this type of cooperative agreements may create a synergistic effect on new knowledge creation (Inkpen \& Pien, 2006). A technology seeking firm may therefore gain a better innovation performance by collaborating with its competitors than by working alone. Furthermore, collaboration provides a good opportunity for firms to measure their competitors' technological levels. Firms that are more knowledgeable about their competitors' technological strategies are better able to differentiate themselves from their competitors. Firms can also learn lessons from their competitor's technological innovation mistakes or problems (Chen et al., 2016).

Hypothesis 3. Technology seeking subsidiaries use more industry- based (in particular competitors) external knowledge collaboration than other types of subsidiaries.

\subsubsection{Technology creating subsidiaries}

In theory, a wider and more diverse search strategy will provide access to new opportunities and enable the firm to build new organizational competences based on the integration of complementary knowledge sets from external agents. For subsidiaries to become competence creating, it has indeed been shown that they must become more closely embedded in local networks in their own immediate environment (Achcaoucaou, Miravitlles, \& León-Darder, 2014; Cantwell \& Mudambi, 2005; Lim, Hemmert, \& Kim, 2017). Hence, competencecreating efforts in MNC subsidiaries entail that they create new knowledge in areas that are not among the traditional strengths of their own MNC group as these activities extend the range of the competencies of the corporate group of which they are part.

Universities and research institutions, in particular, are important centers for creating and disseminating scientific knowledge within or between countries (Hemmert, 2004). A firm choosing not to acquire technological knowledge from universities and research institutions may lag behind state of the art technology, which reduces the likelihood of making a technological breakthrough leading to a commercial product (Tsai \& Wang, 2009). Technological innovation relies heavily on knowledge from universities and research institutions (Bozeman, 2000; McMillan, Narin, \& Deeds, 2000; Nieto \& Santamaría, 2007; Vuola \& Hameri, 2006). Köhler et al. (2012) found that science-driven search is stronger associated with innovation success of more novel innovation than with imitation success. Amara and Landry (2005) results indicate that acquiring knowledge from science-based sources, such as universities, increases the likelihood that the company develops radical new products. Finally, knowledge generated in collaboration with universities is characterized by its scientific and technological nature, high novelty, and a great future potential (Boehm \& Hogan, 2013; Tsai \& Wang, 2009).

Although most research indeed expect that various types of technological partners have a positive effect on technological innovation, some empirical findings are not consistent with these expectations. Caloghirou, Kastelli, and Tsakanikas, (2004) and Ledwith and Coughlan (2005) also found that collaboration with universities and research institutes has a negative effect on product innovation. Furthermore, Lööf and Heshmati (2002) revealed an insignificant relationship between collaboration with research organizations and product innovation. Monjon and Waelbroeck (2003) analyzed French manufacturing firms and found that customer collaboration as well as collaboration with universities and research institutes has a negative effect on product innovation.

In fact, it seems there is also a dark side of industry-based relationships. Intense relationships with customers may result in the initial rejection of new technologies that have the potential to become breakthrough innovations (Du et al., 2014; Gassmann, Enkel, \& Chesbrough, 2010). Furthermore, buyer-supplier relationships can reduce buyers' ability to make objective decisions and increase the likelihood of opportunistic behavior of suppliers (Villena, Revilla, \& Choi, 2011). Furthermore, Lööf and Heshmati (2002) analyzed Swedish manufacturing firms and found a negative relationship between customer collaboration and product innovation. Nieto and Santamaría (2007) also found that customer collaboration only has a marginal positive impact on product innovation. Belderbos et al. (2004) revealed an insignificant association between collaboration with customers and changes in new product sales.

Furthermore, Eisenhardt and Tabrizi (1995) show that supplier knowledge integration has a positive but weak impact on technological innovation. Perez and Sánchez (2003) also fail to confirm that including a supplier's technological knowledge improve a firm's ability to enhance innovation. Freel (2003) analyzed small and medium-sized 
manufacturing firms and found that supplier collaboration does not have a significant impact on new product development. Ledwith and Coughlan (2005) found an insignificant correlation between collaboration with suppliers and product innovation in a sample of electronics firms. In addition, Belderbos et al. (2004) found a negative but insignificant relationship between collaboration with suppliers and product innovation for Dutch manufacturing firms.

However, Leiponen and Helfat (2011) found that knowledge acquisition from customers, suppliers and universities, in this order, increases the likelihood that firms develop new products. In a similar vein, Vega-Jurado, Gutiérrez-Gracia, Fernández-de-Lucio, and Manjarrés-Henríquez, (2008) found that both industrial and science sources increase the degree of innovation. Zhang et al. (2009) found that knowledge flows from competitors and customers are positively correlated to product innovation and Murovec and Prodan (2009) find that information from suppliers, customers and competitors is the most influential in spanning firms' new products portfolio. Nieto and Santamaría (2007) find that collaboration with suppliers, customers and research organization such as universities, positively impacts on novelty of product innovation, whereas cooperation with competitors have a negative effect on this variable. Furthermore, Sofka and Grimpe (2010) found that the so-called science-driven and supply-driven (suppliers) search strategies have a positive impact on radical new product introduction. On the other hand, the market-driven search strategy (customers and competitors) has no effect on this type of innovation.

Taken together, these results suggest that knowledge creation requires a combination of both science-based knowledge sources and industry-based knowledge sources in order to yield successful new product creation.

Hypothesis 4. Technology creating subsidiaries use more industrybased knowledge sources as well as science-based knowledge sources than other types of subsidiaries.

\section{Data and preliminary facts}

To investigate the drivers of research and innovation of foreign firms, we use data from three different sources. The first source of data is the Community Innovation Survey data (CIS4), which are used to obtain information on foreign firms' R\&D and innovation, on their export intensity and on their reliance on external knowledge sources. This wave has been specifically selected because of the presence of data on exporting, which has been dropped in later CIS waves. The second data source is Belfirst (Bureau van Dijk, 2006), which includes annual accounts data for the firms in the CIS4 data, which we use to obtain control variables for the empirical estimations. Finally, the third source of information is the CIS3 data, which are used to calculate lagged spillover variables.

\subsection{Research and innovation data}

The innovation data are taken from the Community Innovation Survey for Belgium and were obtained from the Belgian Science Policy ${ }^{1}$. The sample of firms consists of 3322 firms. Innovating firms are defined as firms with innovation activities over the period considered. This further limits the sample to 1206 firms, of which 374 firms are foreign innovators.

As hypothesized in Section 2, different types of foreign affiliates need to properly align their linkages to local knowledge sources in the host country. Linkages between the multinational affiliate and clients,

\footnotetext{
${ }^{1}$ We would like to thank Manu Monard, Peter Teirlinck and the CFS-STAT Commission for allowing us to access the data, for their hospitality during visits there and for answering questions related to the data.
}

competitors, suppliers and other sources can improve the firm's embeddedness in the host country environment and can properly stimulate its research efforts. Knowledge sources included in the CIS questionnaire are (a) internal R\&D, (b) industry-based collaboration: suppliers, competitors, clients, consultants or other commercial organization (private institutions), (c) science-based collaboration: universities and higher education institutes, public research institutes; and (d) other sources: conferences and trade fairs, scientific publications and professional and industry associations.

We will analyze any differences in the use of the different knowledge sources for the four types of foreign subsidiaries through a multinomial logit analysis. As such, our dependent variable is the type of innovation of the foreign subsidiaries, ranging between standard technology exploiting firms, new technology exploiting subsidiaries, technology seeking and technology creating subsidiaries. This will allow finding out whether the type of subsidiary innovation is a significant boundary condition for the use of the different industry-based and science-based knowledge sources.

For the first sets of regressions, we carried out principal component analysis (PCA) to develop relevant clusters of external knowledge sources (Hervas-Oliver, Sempere-Ripoll, \& Boronat-Moll, 2014). The PCA clearly confirms that suppliers, competitors and clients form a clear-cut industry-based knowledge source factor, while universities and private and public research institutions form a second sciencebased group of external knowledge sources.

However, although the correlation between the industry-based knowledge sources and science-based knowledge sources is low (0.05), there is a high degree of overlap between them. In 42 percent of subsidiaries both sources overlap, i.e. they were both deemed unimportant or both deemed important in the innovation process by the subsidiaries. To tackle this issue, we redefine the knowledge source variables in such a way that they no longer overlap. This leads to three new variables: (i) Only industry sources: dummy equal to one if the firm values industry sources as highly important and does not value science sources as highly important in their innovation; (ii) Only science sources: dummy indicating that the firm values science-based sources as highly important, but not industry sources; and (iii) both knowledge sources: equal to one if the firm values both knowledge sources as highly important for their innovation. The second set of regressions can therefore determine whether the separate or combined use of industry and science-based knowledge sources is an important consideration.

The third and final set of regressions analyzes the specific impact of the individual external knowledge sources separately in order to ascertain which knowledge sources specifically feed into the innovation of different types of foreign subsidiaries.

Table 1 splits the sample into firms according to whether they report positive internal R\&D expenditures. ${ }^{2}$ Out of 374 foreign firms in the sample, 156 are firms that do not engage in R\&D and 218 affiliates report positive internal $R \& D$ expenditures.

Given our interest in external knowledge sources, we will focus on the industry-based sources and science-based sources, distinguishing between clients, competitors, suppliers, and universities, private and public research institutes. Table 1 provides some preliminary evidence on the importance of each of these knowledge sources, distinguishing firms according to their R\&D status. The knowledge source variables are dummies, equal to one if the firm values that particular source as very important in shaping its research activities. From Table 1, it is clear that firms engaging in internal R\&D activities value the importance of external knowledge higher (on average), compared to the firms with no internal research activities. With the exception of suppliers, this is the case for all the external sources listed in the table.

\footnotetext{
${ }^{2}$ Sectors in Fig. 1 are classified according to their technological intensity using the classification of Eurostat. Appendix Table A2 provides the breakdown of the classification into 2-digit NACE codes.
} 
Table 1

Summary statistics.

\begin{tabular}{lll}
\hline Variable & $\begin{array}{l}\text { Non-R\&D } \\
\text { performers }\end{array}$ & R\&D performers \\
\hline Number of firms & 156 & 218 \\
& $(41.71 \%)$ & $(58.29 \%)$ \\
Employment & 222.49 & 275.31 \\
(Number of employees, full time & $(727.60)$ & $(408.99)$ \\
$\quad$ equivalents) & & \\
Labor productivity & 92.05 & $117.68^{* *}$ \\
(Net value added/employee, € x 1000) & $(60.09)$ & $(177.70)$ \\
Export intensity & 32.59 & $56.94^{* * *}$ \\
(Exports/sales) & $(37.01)$ & $(40.94)$ \\
Supplier knowledge sources & 0.28 & 0.27 \\
Firm-level dummy variable & $(0.45)$ & $(0.44)$ \\
Competitor knowledge sources & 0.17 & $0.24^{*}$ \\
Firm-level dummy variable & $(0.38)$ & $(0.43)$ \\
Client knowledge sources & 0.29 & $0.56^{* * *}$ \\
Firm-level dummy variable & $(0.46)$ & $(0.50)$ \\
Private institutions knowledge sources & 0.06 & 0.09 \\
Firm-level dummy variable & $(0.25)$ & $(0.29)$ \\
Universities knowledge sources & 0.03 & $0.10^{* * *}$ \\
Firm-level dummy variable & $(0.18)$ & $(0.30)$ \\
Public knowledge sources & 0.00 & $0.05^{* * *}$ \\
Firm-level dummy variable & - & $(0.21)$ \\
R\&D spillover effects & 0.02 & 0.02 \\
Defined at two-digit industry level, using & $(0.06)$ & $(0.07)$ \\
CIS3 data & & \\
R\&D demonstration effects & 0.01 & $0.03^{* * *}$ \\
Defined at two-digit industry level, using & $(0.03)$ & $(0.05)$ \\
$\quad$ CIS3 data & & \\
\hline & & \\
\hline & & \\
\hline
\end{tabular}

Values are means (standard deviations). Variables are defined in Appendix A. Sigfnificance levels refer to one-tailed $t$-test of difference in means. ${ }^{*} \mathrm{p}<0.10$, $* * \mathrm{p}<0.05, * * * \mathrm{p}<0.01$.

\begin{tabular}{|c|c|c|c|}
\hline \multicolumn{2}{|l|}{ Total $\mathrm{N}=374$ foreign subsidiaries } & \multicolumn{2}{c|}{ New to local market } \\
\cline { 2 - 4 } & YES & Technology creating & Technology seeking \\
\hline & & $\mathrm{N}=108$ & $\mathrm{~N}=80$ \\
\cline { 3 - 4 } & & New technology & Standard technology \\
& & exploiting & exploiting \\
& & $\mathrm{N}=71$ & $\mathrm{~N}=115$ \\
\hline
\end{tabular}

Fig. 2. Subsidiary innovation typology: Belgian data.

As can be seen in Fig. 1, about half of multinational subsidiaries in our sample introduce innovations that are new to the market (new technology exploiting or technology creating). Moreover, more than a quarter introduce innovation that are both new to the market and new to the firm (technology creating). About half of the MNCs in our sample introduce innovations that are already present in the Belgian market and about a quarter are technology seeking (i.e. they introduce an innovation that is new to the firm, but not new to the market). Given that Belgium is one of the countries with the highest share of innovative companies and highest share of foreign subsidiaries in expenditure on $\mathrm{R}$ \&D (European Commission, 2012, 2018), it can serve as a useful example for many countries around the world given the increasing internationalization of R\&D and innovation. It should be clear, however, that the exact distribution of different subsidiary types is obviously host country-specific (Fig. 2).

Technology creating firms spend more on internal R\&D than all the other firm types, both in absolute terms and relative terms, i.e. they account for the majority of total internal R\&D spending by foreign subsidiaries in the sample and they report the highest average firmlevel internal R\&D intensity. They also cooperate more with other firms and they have a higher likelihood of attracting funding (from regional, national or EU sources). They also account for 31 percent of total external R\&D spending by multinational firms in Belgium.

New technology exploiting subsidiaries on the other hand account for a smaller share of total internal R\&D spending, but they account for the large majority of external R\&D spending, accounting for 68 percent of the sample total. Overall, in terms of total R\&D spending, firms that introduce an existing innovation in a new market are the largest R\&D spenders in the sample.

Technology seeking firms, introducing an innovation that is new to the firm but not new to the market account for 21 percent of firms, but only 4 percent of total $R \& D$ spending. Their average firm-level $R \& D$ intensity is much lower compared to firms that introduce a novel innovation in the market (new technology exploiting and technology creating firms). They also cooperate less and are less likely to acquire funding.

Finally, standard technology exploiting firms, exploiting innovations that already exist in the market and within the firm boundaries account for a fair share of the total number of subsidiaries but for less than 1 percent of total R\&D spending (internal or external). Somewhat surprisingly, the majority of these firms still engage in internal $R \& D$ spending, but the magnitude of their spending is much lower compared to the other firm types listed in the table.

\subsection{Control variables}

First and foremost, we need to control for R\&D intensity of the subsidiary firm. Firms that carry out R\&D have been shown to be more innovative (Castellani, Montresor, Schubert, \& Vezzani, 2017; Frenz \& Ietto-Gillies, 2009). We define R\&D intensity as the ratio of the firm's total internal R\&D expenditures, divided by its turnover. R\&D intensity is a censored variable, equal to zero if the firm had no internal $R \& D$ expenditures.

In addition to internal R\&D, multinational subsidiaries' innovation is expected to depend on the potential for spillover effects. Technological spillovers refer to the impact of research activities by competitors on the focal firm. Although most research has thereby focused on the impact of MNCs on local firms (Blomström \& Kokko, 1998; Ha \& Giroud, 2015), we will control for the spillover effects of other host country firms on MNC affiliates. To the extent that higher research efforts within the sector are complementary to the firm's own R\&D efforts, foreign affiliates are expected to increase their own innovation in response to an increase in R\&D spending within its sector (Belderbos, Leten, \& Suzuki, 2017).

We thereby make a distinction between internal R\&D and external $R$ \&D sources of competitors. Host country firms will make an effort to limit the unintended transfer of knowledge to other same-sector firms. In this context, it is likely to be more straightforward for firms to protect the knowledge generated within the firms' boundaries, while it is relatively harder to guard the knowledge flows resulting from its external R\&D efforts (Belderbos et al., 2004).

Internal R\&D efforts by firms' competitors are hypothesized to have a demonstration effect on other firms within the same sector, causing them to increase their innovation efforts. To the extent that external R\& $\mathrm{D}$ is subject to a higher risk of unintended leakages of knowledge compared to internal R\&D, it can be expected that external R\&D spillovers might have a positive spillover effect, acting as a catalyst to firmlevel innovation.

To identify within-sector internal and external R\&D spillover effects, we will therefore include an internal R\&D demonstration effect term and an external R\&D spillover effect term. Specifically, internal R\&D 
Table 2

Regression results: Multinomial logit analysis of subsidiary technological activities (marginal effects).

\begin{tabular}{|c|c|c|c|c|}
\hline Variables & Standard technology & Technology exploiting & $\begin{array}{l}\text { Technology } \\
\text { Seeking }\end{array}$ & $\begin{array}{l}\text { Technology } \\
\text { Creating }\end{array}$ \\
\hline Internal $R \& D$ intensity & $-0.008^{*}$ & 0.003 & 0.001 & 0.004 \\
\hline$=\mathrm{R} \& \mathrm{D}$ expenses as a share of total turnover & {$[0.004]$} & [0.003] & {$[0.003]$} & [0.003] \\
\hline $\ln ($ Employment $)$ & 0.003 & 0.006 & -0.014 & 0.005 \\
\hline$=\log$ of number of employees & {$[0.020]$} & {$[0.017]$} & {$[0.019]$} & {$[0.020]$} \\
\hline $\ln$ (Labor productivity) & 0.010 & $0.085^{* * *}$ & $-0.064 *$ & -0.030 \\
\hline$=\log$ of value added per worker & [0.039] & {$[0.033]$} & {$[0.039]$} & [0.042] \\
\hline Export intensity & -0.000 & -0.001 & 0.000 & 0.000 \\
\hline$=$ export turnover as a share of total turnover & {$[0.001]$} & {$[0.001]$} & {$[0.001]$} & {$[0.001]$} \\
\hline Industry-based knowledge sources & $-0.117^{*}$ & -0.002 & 0.017 & $0.101 * *$ \\
\hline$=$ PCA factor & {$[0.046]$} & {$[0.041]$} & [0.044] & {$[0.048]$} \\
\hline Science-based knowledge sources & -0.029 & 0.017 & -0.094 & $0.105^{*}$ \\
\hline$=$ PCA factor & {$[0.073]$} & {$[0.062]$} & {$[0.076]$} & {$[0.055]$} \\
\hline R\&D demonstration effects & $4.250 * *$ & -5.153 & -1.094 & 1.996 \\
\hline$=$ Lagged internal R\&D at industry level & [1.849] & [3.194] & [2.322] & [1.675] \\
\hline R\&D spillover effects & $-1.274^{*}$ & 1.113 & 0.100 & 0.061 \\
\hline$=$ Lagged external R\&D at industry level & {$[0.743]$} & [1.102] & [0.853] & {$[0.694]$} \\
\hline \multirow[t]{2}{*}{ High-tech manufacturing dummy } & $-0.196^{* * *}$ & 0.054 & 0.037 & 0.105 \\
\hline & {$[0.074]$} & {$[0.076]$} & {$[0.071]$} & {$[0.065]$} \\
\hline \multirow[t]{2}{*}{ HT knowledge int. services dummy } & 0.048 & -0.010 & 0.006 & -0.045 \\
\hline & [0.101] & {$[0.081]$} & [0.093] & {$[0.110]$} \\
\hline \multirow[t]{2}{*}{ LT knowledge int. services dummy } & $0.116^{*}$ & $-0.145^{*}$ & -0.020 & 0.049 \\
\hline & {$[0.068]$} & {$[0.065]$} & [0.067] & [0.073] \\
\hline \multirow[t]{2}{*}{ Other sectors } & 1.164 & 0.441 & 0.805 & -2.410 \\
\hline & [44.718] & [29.749] & {$[35.085]$} & [109.547] \\
\hline Non-EU HQ dummy & -0.020 & -0.018 & -0.003 & 0.041 \\
\hline$=1$ if $\mathrm{HQ}$ is non-European & {$[0.060]$} & {$[0.050]$} & {$[0.056]$} & {$[0.054]$} \\
\hline Entry mode & $0.105^{*}$ & -0.059 & 0.001 & -0.047 \\
\hline$=1$ if acquisition & [0.047] & {$[0.043]$} & [0.045] & [0.047] \\
\hline \multirow[t]{2}{*}{ Brussels region dummy } & $-0.206^{* * *}$ & 0.088 & 0.101 & 0.017 \\
\hline & {$[0.075]$} & {$[0.062]$} & [0.053] & [0.055] \\
\hline \multirow{2}{*}{ Flemish region dummy } & -0.077 & -0.015 & 0.031 & 0.061 \\
\hline & [0.053] & {$[0.050]$} & [0.053] & [0.055] \\
\hline
\end{tabular}

demonstration effects are defined as the sum of total internal R\&D in a certain sector, divided by the sales of that sector. External spillovers are defined analogously using the sum of lagged external R\&D in a particular sector.

We therefore use lagged data from the Community Innovation Survey (CIS3) for Belgium. This implies that the variables for internal and external R\&D at the industry level are lagged one CIS survey period (4 years) in order to avoid a simultaneity bias. The two variables, which are defined at the two-digit sector (NACE) level, are also summarized in Table 1. Firms engaging in R\&D tend to be active in sectors characterized by a higher internal R\&D intensity on average, compared to firms that do not engage in internal research efforts. For external R\&D spillovers, there appear to be no significant differences between the two types of firms.

Furthermore, affiliates that become overly embedded in their host country environment may be viewed as confined by headquarters, losing credibility within the organization and being cut off from future developments or flows of strategic resources and knowledge (Achcaoucaou et al., 2014; Brenner \& Ambos, 2013). Furthermore, being more autonomous does not necessarily entail an improved role in the multinational network (Jarillo \& Martínez, 1990). In order to avoid a research effort that is detached from or incommensurate to the rest of the multinational network, more research intensive affiliates are expected to export more. A foreign firm with higher productivity can, ceteris paribus, free up more resources to spend on R\&D and innovation compared to its less productive competitors. Hence, productivity is also supposed to play a positive role in a firm's innovativeness (Castellani et al., 2017). Cassiman and Golovko (2011) show, for instance, for a sample of Spanish manufacturing firms that firms engaged in R\&D stochastically dominate firms without R\&D activities in terms of their productivity.

By merging the CIS4-data with annual accounts data from Belfirst, it is possible to calculate firm-level labor productivity for all the firms in our sample. Labor productivity is defined as net value added per employee. ${ }^{3}$ Table 1 compares labor productivity for the group of R\&D performers versus non-R\&D performers among the foreign firms. From Table 1 , it is also clear that foreign firms engaging in R\&D tend to be larger (in terms of employment), more productive and they have a higher export intensity on average, compared to firms that have no internal R\&D spending.

\section{Result and discussion}

Table 2 reports the results for the first set of multinomial logistic regressions. As indicated, the variables of interest on industry-based and science-based knowledge sources were created using a principal component analysis. Marginal effects are reported in order to allow for a comparison across the four types of subsidiaries. The results indicate that standard technology exploiting subsidiaries have significantly less collaboration with industry-based partners than the other type of subsidiaries. The results also indicate specifically that technology seeking subsidiaries have less access to science-based knowledge sources while technology creating subsidiaries have an enhanced access to both industry-based and science-based partners.

These results are confirmed in Table 3 where the industry-based and science-based partners are further disentangled, creating variables for subsidiaries that use either type of knowledge source or a combination thereof. From Table 3 we can see that technology creating firms not only need to establish collaboration with science-based partners but also with industry-based companies given that the marginal effect of the use of both types of knowledge sources is significantly higher than

\footnotetext{
${ }^{3}$ Variables are defined in Appendix A.
} 
Table 3

Regression results: Multinomial logit analysis of subsidiary technological activities (marginal effects).

\begin{tabular}{|c|c|c|c|c|}
\hline Variables & Standard technology & Technology exploiting & $\begin{array}{l}\text { Technology } \\
\text { Seeking }\end{array}$ & $\begin{array}{l}\text { Technology } \\
\text { Creating }\end{array}$ \\
\hline Internal $\mathrm{R} \& \mathrm{D}$ intensity & $-0.008^{*}$ & 0.003 & 0.001 & 0.004 \\
\hline$=\mathrm{R} \& \mathrm{D}$ expenses as a share of total turnover & {$[0.004]$} & [0.003] & [0.003] & [0.003] \\
\hline $\ln ($ Employment $)$ & 0.004 & 0.006 & -0.014 & 0.004 \\
\hline$=\log$ of number of employees & {$[0.020]$} & [0.017] & [0.019] & {$[0.020]$} \\
\hline $\ln ($ Labor productivity) & 0.010 & $0.085^{* * *}$ & $-0.063^{*}$ & -0.032 \\
\hline$=\log$ of value added per worker & [0.039] & {$[0.033]$} & {$[0.038]$} & [0.042] \\
\hline Export intensity & -0.000 & -0.001 & 0.000 & 0.000 \\
\hline$=$ export turnover as a share of total turnover & {$[0.001]$} & {$[0.001]$} & {$[0.001]$} & {$[0.001]$} \\
\hline Only industry-based knowledge sources & $-0.107 * *$ & -0.008 & 0.032 & $0.084 *$ \\
\hline$=1$ if industry sources $=1 \&$ science sources $=0$ & [0.049] & [0.043] & {$[0.046]$} & {$[0.051]$} \\
\hline Only science-based knowledge sources & 0.013 & -0.026 & 0.011 & 0.002 \\
\hline$=1$ if science sources $=1 \&$ industry sources $=0$ & [0.110] & [0.118] & [0.115] & {$[0.130]$} \\
\hline Both knowledge sources & -0.160 & 0.040 & -0.119 & $0.239 * * *$ \\
\hline$=1$ if science sources $=1 \&$ industry sources $=1$ & [0.102] & [0.077] & {$[0.107]$} & {$[0.083]$} \\
\hline R\&D demonstration effects & $4.211^{* *}$ & -5.134 & -1.119 & 2.042 \\
\hline$=$ Lagged internal R\&D at industry level & [1.857] & [3.189] & {$[2.346]$} & [1.681] \\
\hline R\&D spillover effects & $-1.254^{*}$ & 1.104 & 0.115 & 0.036 \\
\hline$=$ Lagged external R\&D at industry level & {$[0.746]$} & [1.102] & {$[0.858]$} & [0.696] \\
\hline \multirow[t]{2}{*}{ High-tech manufacturing dummy } & $-0.195^{* * *}$ & 0.054 & 0.037 & 0.104 \\
\hline & {$[0.073]$} & {$[0.076]$} & {$[0.071]$} & [0.065] \\
\hline \multirow[t]{2}{*}{ HT knowledge int. services dummy } & 0.049 & -0.011 & 0.010 & -0.048 \\
\hline & [0.102] & [0.081] & [0.093] & [0.109] \\
\hline \multirow[t]{2}{*}{ LT knowledge int. services dummy } & $0.113^{*}$ & $-0.144 * *$ & -0.023 & 0.053 \\
\hline & [0.068] & {$[0.065]$} & {$[0.066]$} & [0.073] \\
\hline \multirow[t]{2}{*}{ Other sectors } & 1.187 & 0.455 & 0.825 & -2.467 \\
\hline & [51.595] & [34.628] & [40.340] & {$[126.561]$} \\
\hline Non-EU HQ dummy & -0.017 & -0.020 & -0.000 & 0.037 \\
\hline$=1$ if $\mathrm{HQ}$ is non-European & {$[0.060]$} & {$[0.050]$} & {$[0.056]$} & {$[0.055]$} \\
\hline Entry mode & $0.105^{* *}$ & -0.059 & 0.002 & -0.047 \\
\hline$=$ Acquisition dummy & [0.047] & [0.043] & [0.045] & {$[0.047]$} \\
\hline \multirow{2}{*}{ Brussels region dummy } & $-0.203^{* * *}$ & 0.087 & 0.105 & 0.011 \\
\hline & {$[0.075]$} & {$[0.062]$} & [0.067] & {$[0.077]$} \\
\hline \multirow[t]{2}{*}{ Flemish region dummy } & -0.076 & -0.015 & 0.032 & 0.059 \\
\hline & [0.053] & {$[0.050]$} & [0.053] & [0.055] \\
\hline
\end{tabular}

for technology creating subsidiaries that only have access to either type of knowledge sources. In fact, science-based knowledge collaboration alone does not seem to have a positive and significant impact on knowledge creation. Only when these types of subsidiaries have access to both types of partners are they able to create new knowledge.

In order to further disentangle the importance of the specific external knowledge sources for the different types of subsidiaries, we ran multinomial logit regressions on the four types of technology exploiting and exploring subsidiaries for all the external knowledge sources separately. Table 4 reports the marginal effects of the various knowledge sources and again indicates that there are indeed significant differences between these four types of firms.

In fact, client knowledge sources are shown to be a more important driver for technology creating subsidiaries while they are significantly less important for standard technology exploiting affiliates. Furthermore, knowledge collaboration with competitors specifically is an important knowledge source for technology seeking subsidiaries. As far as science-based knowledge sources are concerned, universities are now shown to matter for technology creating types of subsidiaries as compared to the other three types of firms.

As far as the control variables are concerned, the results from both regression tables support some interesting conclusions. First, there is a significant distinction in the research intensity of the various types of subsidiaries. Standard technology exploiting subsidiaries carry out significantly less research than the other types of subsidiaries, although no further significant differences are detected between the other three types of subsidiaries. This is also important in and of itself, given that the three other types of subsidiaries all carry out a significant amount of R\&D. Second, there are some significant differences in terms of labor productivity between the subsidiaries. As such, technology-exploiting subsidiaries are clearly more productive than the more technology seeking and creating subsidiaries.

In terms of lagged R\&D demonstration and spillover effects, it is interesting to see that standard technology exploiting subsidiaries have competitors that demonstrate an internal $R \& D$ intensity that is substantially and significantly higher while external R\&D intensity is substantially and significantly lower. Clearly, these firms cannot benefit from spillovers and cannot compete in terms of innovation against their research intensive competitors. More surprisingly, these are more often than not acquired companies.

In summary, we can conclude that hypothesis 4 can be accepted, meaning that knowledge creating subsidiaries use both science and industry-based collaboration in their innovation process. In particular, a combination of client and university collaboration seems necessary to establish knowledge creation that is new to the firm and the market. It is also important to note that the use of science-based partners alone does not seem to be sufficient. Hypothesis 3 has also been confirmed, in that technology seeking subsidiaries do seem to rely more on industrybased sourcing, from competitors in particular. It is also important to note that these types of subsidiaries also rely less on access to sciencebased knowledge sources.

Hypotheses 1, however, has only received partial support in that standard technology exploiting subsidiaries typically use less industrybased collaboration, in particular, clients. Hypothesis 2 cannot be confirmed either. If anything, the results indicate that knowledge exploiting firms do not use much external knowledge collaboration of any kind. 
Table 4

Regression results: Multinomial logit analysis of subsidiary technological activities (marginal effects).

\begin{tabular}{|c|c|c|c|c|}
\hline Variables & Standard technology & Technology Exploiting & $\begin{array}{l}\text { Technology } \\
\text { Seeking }\end{array}$ & $\begin{array}{l}\text { Technology } \\
\text { Creating }\end{array}$ \\
\hline Internal $\mathrm{R} \& \mathrm{D}$ intensity & $-0.008^{*}$ & 0.003 & 0.002 & 0.003 \\
\hline$=\mathrm{R} \& \mathrm{D}$ expenses as a share of total turnover & {$[0.004]$} & [0.003] & [0.003] & [0.003] \\
\hline $\ln ($ Employment $)$ & 0.005 & 0.006 & -0.014 & 0.003 \\
\hline$=\log$ of number of employees & {$[0.020]$} & [0.017] & [0.019] & [0.019] \\
\hline $\ln$ (Labor productivity) & 0.018 & $0.090 * * *$ & $-0.074^{*}$ & -0.034 \\
\hline$=\log$ of value added per worker & [0.039] & [0.033] & [0.038] & [0.042] \\
\hline Export intensity & -0.000 & -0.001 & 0.000 & 0.001 \\
\hline$=$ export turnover as a share of total turnover & [0.001] & {$[0.001]$} & {$[0.001]$} & [0.001] \\
\hline Supplier knowledge sources & -0.013 & 0.003 & -0.037 & 0.047 \\
\hline$=1$ if supplier knowledge sources $=1$ & [0.054] & [0.047] & {$[0.050]$} & [0.053] \\
\hline Competitors knowledge sources & -0.061 & -0.067 & $0.100^{*}$ & 0.028 \\
\hline$=1$ if competitor knowledge sources $=1$ & [0.065] & {$[0.057]$} & [0.053] & {$[0.060]$} \\
\hline Client knowledge sources & $-0.132^{* * *}$ & 0.036 & 0.008 & $0.088^{*}$ \\
\hline$=1$ if client knowledge sources $=1$ & [0.049] & [0.042] & [0.046] & [0.047] \\
\hline Private research institutes knowledge sources & 0.065 & 0.079 & -0.084 & -0.061 \\
\hline$=1$ if private research institute knowledge sources $=1$ & [0.093] & {$[0.080]$} & {$[0.106]$} & {$[0.101]$} \\
\hline University knowledge sources & -0.206 & 0.038 & 0.017 & $0.150^{*}$ \\
\hline$=1$ if university knowledge sources $=1$ & [0.132] & [0.092] & {$[0.110]$} & [0.101] \\
\hline Public research institutes knowledge sources & 0.906 & 0.403 & -2.197 & 0.888 \\
\hline$=1$ if public research institute knowledge sources $=1$ & [34.271] & {$[22.776]$} & [90.242] & [33.197] \\
\hline R\&D demonstration effects & $4.471^{* *}$ & $-5.192^{*}$ & -1.287 & 2.007 \\
\hline$=$ Lagged internal R\&D at industry level & [1.843] & [3.152] & {$[2.410]$} & [1.685] \\
\hline R\&D spillover effects & $-1.234^{*}$ & 1.130 & 0.289 & -0.184 \\
\hline$=$ Lagged external R\&D at industry level & {$[0.741]$} & [1.085] & [0.878] & {$[0.700]$} \\
\hline \multirow[t]{2}{*}{ HT manufacturing dummy } & $-0.185^{* *}$ & 0.050 & 0.030 & 0.106 \\
\hline & {$[0.073]$} & {$[0.075]$} & {$[0.072]$} & {$[0.066]$} \\
\hline \multirow[t]{2}{*}{ HT knowledge int. services dummy } & 0.037 & -0.015 & -0.014 & -0.008 \\
\hline & {$[0.101]$} & {$[0.081]$} & [0.094] & [0.109] \\
\hline \multirow[t]{2}{*}{ LT knowledge int. services dummy } & $0.122 *$ & $-0.147 * *$ & -0.025 & 0.050 \\
\hline & [0.068] & {$[0.065]$} & {$[0.067]$} & [0.073] \\
\hline \multirow[t]{2}{*}{ Other sectors } & 1.062 & 0.408 & 0.790 & -2.261 \\
\hline & [37.966] & {$[26.013]$} & {$[30.716]$} & [94.693] \\
\hline Non-EU HQ dummy & -0.035 & -0.021 & 0.012 & 0.045 \\
\hline$=1$ if $\mathrm{HQ}$ is non-European & {$[0.060]$} & {$[0.051]$} & {$[0.056]$} & [0.054] \\
\hline Entry mode & $0.106^{* *}$ & -0.054 & 0.005 & -0.057 \\
\hline$=$ Acquisition dummy & [0.047] & [0.043] & [0.044] & {$[0.047]$} \\
\hline \multirow[t]{2}{*}{ Brussels region dummy } & $-0.190^{* *}$ & 0.087 & 0.099 & 0.004 \\
\hline & {$[0.075]$} & [0.062] & [0.067] & {$[0.078]$} \\
\hline \multirow[t]{2}{*}{ Flemish region dummy } & -0.060 & -0.019 & 0.022 & 0.057 \\
\hline & [0.053] & {$[0.049]$} & [0.052] & [0.054] \\
\hline
\end{tabular}

\section{Conclusions and recommendations}

This paper has focused on the innovation of foreign subsidiaries. It has thereby specifically analyzed the importance of external knowledge sources as drivers of their innovation. It has distinguished between four types of foreign subsidiaries depending on the type of innovation that takes place at the subsidiary. Using a matrix of innovations new to the market and new to the firm, we have created a typology of four types of subsidiaries: standard technology exploiting (innovations not new to the market and not new to the firm), new technology exploiting (innovations new to the market but not new to the firm), technology seeking (innovations new to the firm but not new to the market), and technology creating (innovations new to the firm and new to the market).

We have explored how different open innovation knowledge sources facilitated their different product innovation outcome. In particular, we have analyzed the role of external knowledge that flows vertically across industries, both upstream from suppliers and downstream from clients, as well as external knowledge inputs stemming horizontally from competitors in the same industry. We have also looked at the importance of sciencebased collaboration with universities and research institutions.

Local embeddedness of a firm, as measured by its external linkages to industry- and science-based partners, is found to be able to contribute positively to firms' innovation albeit not across the board. As such, we cannot draw a one-for-all conclusion for all of these types of subsidiaries, which might explain the contradictory results that can be found in literature regarding the use of various knowledge sources in driving the innovation of firms. Our results clearly indicate that the use of industry-based and science-based knowledge sources is very much dependent on the type of subsidiary. Our results suggest that a useful improvement on the existing literature consists in an analysis that does not merely focus on the quantitative contribution of external knowledge to innovation but rather investigates the variety of the sources of external knowledge and their differentiated impact on subsidiary innovation. Our results support the hypothesis that the matching between sources of external knowledge and types of innovation is necessary to implement successful innovation strategies.

Our study sheds some light on the preferable combination of innovation collaboration under which innovation leadership positions can be attained. Specifically, when we analyze the separate or combinatory impact of industry- and science-based knowledge sources for knowledge creation, the results indicate that science-based knowledge sources are not very useful by themselves unless they are combined with industry-based knowledge sources for knowledge creation. In particular, client knowledge sources and university knowledge sources are shown to drive technology creation.

As far as technology seeking is concerned, collaboration with competitors is shown to be specifically instrumental. In fact, technology seeking subsidiaries rely for the most part on collaboration with their competitors for this innovation strategy. The results also clarify that these types of subsidiaries make significantly less use of science-based collaborations.

Technology exploiting subsidiaries do not make much use of 
research collaboration. Standard technology exploiting subsidiaries, for instance, use significantly less collaboration with clients in their innovation process. New technology exploiting subsidiaries are nonetheless very efficient (in terms of labor productivity) in their application of existing MNC technology.

The fact that industry-based knowledge sources as well as sciencebased knowledge sources can act as a vital knowledge source, points to the importance of local factors in shaping multinationals' research activities. Understanding knowledge exploiting and exploring is critical for managers and policy makers alike.

The results also indicate that knowledge seeking, i.e., sourcing existing knowledge in the host market that is, however, new to the MNC requires collaboration with competitors. As far as technology exploiting subsidiaries are concerned, the results indicate that not much external partner collaboration is needed to be effective and efficient.

In summary, the results indicate that it is essential to understand the use(fulness) of different external partners depending on the desired innovation outcome. As such, the results also inform subsidiary managers what they could do to try to take subsidiary initiative in terms of their innovation outcome and perhaps change their subsidiary mandate (Dörrenbächer \& Gammelgaard, 2016; Lim et al., 2017; Schmid, Dzedek, \& Lehrer, 2014; Strutzenberger \& Ambos, 2014).

However, affiliates that become overly embedded in their host country environment may be viewed as confined by headquarters, losing credibility within the organization and being cut off from future developments or flows of strategic resources and knowledge. Being more autonomous does not necessarily entail an improved role in the multinational network (Jarillo \& Martínez, 1990). In order to avoid a research effort that is detached or incommensurate from the rest of the multinational network, more research intensive affiliates are exporting more. Hence, it seems that, in order to avoid research efforts by subsidiaries for the benefit of the local economy rather than for the benefit of global markets, more research intensive affiliates are given more market scope.

As far as entry mode is concerned, the results indicate that acquired companies have a high research intensity but are mostly standard exploiting subsidiaries. As such, foreign multinationals seem to be better off giving strategic autonomy to greenfield subsidiaries to build embeddedness by linking to local industry and science partners rather than acquiring a local company in the hope of creating new knowledge.

These findings also suggest an important, albeit indirect, role for the government in increasing foreign firms' research efforts. Previous research has already indicated that specific policies aimed at attracting foreign innovative activity might be less efficient compared to policies designed at fostering research activity within certain well-targeted sectors and firms (Teirlinck, 2005). As such, costly policies aimed solely at the attraction of foreign research spending can be considered inferior to policies aimed at improving the research activities of these foreign firms. For policy makers, the presumption has been that inward FDI is beneficial for innovation. However, if many foreign firms enter sourcing existing knowledge, these gains may not accrue and a nation's technological uniqueness might be more quickly replicated. Therefore, our results suggest that the government has a more indirect role to play, by fostering public and private research collaboration, which induces more creative innovation from foreign subsidiaries. This, in turn, means that universities have an important role to play in stimulating foreign firms' research and development efforts also in collaboration with industrial partners, especially customers. As such, locational resources can be used for the creation of MNC locational capital (Zaheer \& Nachum, 2011). As a result of the limits to appropriation in the creation of firm-specific locational capital, MNCs can also contribute to transforming the location itself.

\section{Appendix A. Data and definitions}

\section{Dependent variable}

Type of innovation of foreign subsidiary (ranging from 1 to 4 )

Standard technology exploiting $=1$

New technology exploiting $=2$

Technology seeking $=3$

Technology creating $=4$

\section{Independent variables}

R\&D intensity: Intra-mural expenditures on research and development, in thousands of euros divided by Sales (Turnover, thousands of euros). Specific question from the CIS-survey: "Please estimate the amount of expenditure on intramural R\&D (including personnel and related costs) as well as capital expenditures on buildings and equipment specifically for R\&D only."

Source: Community Innovation Survey.

Employment: Number of employees, full-time equivalents.

Source: Community Innovation Survey Belgium.

Export intensity: Share of exports in sales, value between 0 and 1.

Source: Community Innovation Survey Belgium.

Labor productivity: Net value added per employee, thousands of euros.

Source: Belfirst, Bureau van Dijk.

Born BE: Dummy variable indicating an acquisition entry mode

Source: Zephyr, Bureau van Dijk.

Non EU: Dummy variable indicating a non-European HQ

Source: Belfirst, Bureau van Dijk.

\section{Firm-level knowledge sources}

Firms are asked in the CIS questionnaire to value the importance of several knowledge sources to their innovation activities. Specifically, the question reads: "How important to your enterprise's innovation activities were each of the following information sources? (Please identify sources that provided information for new innovation projects or contributed to the completion of existing innovation projects.)". Firms are asked to mark the importance of each of the knowledge sources according to the following scale: $0=$ not important; $1=$ low importance; $2=$ medium importance; 3 = high importance. 
The knowledge source variables used in the empirical analysis have been recoded to dummy variables, equal to one if a firm has valued that particular source as being highly important. We include six different knowledge sources: Clients, Competitors, Suppliers, Private institutions, Public research institutes and Universities.

\section{Industry spillover and demonstration effects}

To obtain a measure of internal and external R\&D efforts by sector, we sum total R\&D expenditures in that sector of all firms who participated in the previous wave and divide this number by their total sales. This leads to the following definitions for the internal demonstration effects and external spillover effects:

R\&D demonstration effects: Internal R\&D over sales ratio within each 2-digit NACE sector. Definition of internal R\&D in the CIS-questionnaire: "Intramural (in-house) R\&D: creative work undertaken within your enterprise to increase the stock of knowledge and its use to devise new and improved products and processes (including software development)."

R\&D spillover effects: External R\&D over sales ratio within each 2-digit NACE sector. Definition of external R\&D in the CIS-questionnaire: "Extramural R\&D: same activities as above, but performed by other companies or by public or private research organizations and purchased by your enterprise."

See Table A1

\section{Table A1}

Correlation matrix.

\begin{tabular}{|c|c|c|c|c|c|c|c|c|c|c|c|c|}
\hline \multicolumn{2}{|c|}{ Variables } & \multirow{2}{*}{$\frac{[1]}{1.00}$} & \multirow[t]{2}{*}[2]{} & \multirow[t]{2}{*}{ [3] } & \multirow[t]{2}{*}{ [4] } & \multirow[t]{2}{*}{ [5] } & \multirow[t]{2}{*}[6]{} & \multirow[t]{2}{*}{ [7] } & \multirow[t]{2}{*}{ [8] } & \multirow[t]{2}{*}{ [9] } & \multirow[t]{2}{*}{ [10] } & \multirow[t]{2}{*}{ [11] } \\
\hline$[1]$ & $\ln$ (Employment) & & & & & & & & & & & \\
\hline$[2]$ & $\ln$ (Labor productivity) & 0.03 & 1.00 & & & & & & & & & \\
\hline [3] & Export intensity & 0.26 & 0.00 & 1.00 & & & & & & & & \\
\hline [4] & Internal & 0.16 & 0.06 & 0.05 & 1.00 & & & & & & & \\
\hline$[5]$ & Supplier & 0.00 & -0.14 & 0.02 & 0.06 & 1.00 & & & & & & \\
\hline$[6]$ & Competitor & 0.03 & 0.06 & 0.02 & 0.08 & 0.15 & 1.00 & & & & & \\
\hline [7] & Client & 0.10 & 0.04 & 0.18 & 0.11 & 0.09 & 0.35 & 1.00 & & & & \\
\hline [8] & Private insititutions & 0.05 & -0.03 & 0.01 & 0.11 & 0.13 & 0.11 & -0.03 & 1.00 & & & \\
\hline [9] & Universities & 0.06 & 0.00 & 0.03 & 0.07 & 0.08 & 0.11 & -0.02 & 0.37 & 1.00 & & \\
\hline [10] & Public & 0.04 & -0.01 & -0.02 & 0.11 & 0.05 & 0.28 & 0.05 & 0.44 & 0.59 & 1.00 & \\
\hline [11] & R\&D demonstration effects & 0.01 & 0.13 & -0.07 & 0.07 & -0.13 & -0.06 & -0.02 & 0.01 & 0.08 & 0.07 & 1.00 \\
\hline [12] & R\&D spillover effects & -0.10 & -0.01 & -0.12 & 0.03 & -0.06 & -0.02 & 0.00 & 0.03 & 0.09 & 0.15 & 0.42 \\
\hline
\end{tabular}

Correlation matrix of independent variables. Variables are defined in Appendix A.

Table A2

Sector Classification According to Technology Intensity and Knowledge Intensity.

Source: Eurostat.

\begin{tabular}{|c|c|c|c|c|c|}
\hline \multicolumn{3}{|l|}{ Manufacturing } & \multicolumn{3}{|l|}{ Services } \\
\hline Sector & NACE & Description & Sector & NACE & Description \\
\hline \multirow{26}{*}{ High-technology manufacturing } & 244 & Pharmaceuticals & Knowledge-intensive services & 61 & Water transport \\
\hline & 30 & Office machinery - computers & & 62 & Air transport \\
\hline & 32 & Radio, TV, communication equipment & & 64 & Post and telecommunications \\
\hline & 33 & Medical, precision, optical instruments & & 65 & Financial intermediation \\
\hline & 353 & Aircraft - spacecraft & & 66 & Insurance and pension funding \\
\hline & 24 & Chemicals, excl. pharmaceuticals & & 67 & Ancilliary financial activities \\
\hline & 29 & Machinery and equipment & & 70 & Real estate activities \\
\hline & 31 & Electrical machinery & & 71 & Renting activities \\
\hline & 34 & Motor vehicles & & 72 & Computer and related activities \\
\hline & 35 & Other transport equipment (excl. $351 \& 353$ ) & & 73 & Research and development \\
\hline & 25 & Rubber and plastic & & 80 & Education \\
\hline & 26 & Nonmetallic mineral products & & 85 & Health and social work \\
\hline & 27 & Basic metals & & 92 & Recreational activities \\
\hline & 28 & Fabricated metal products & Less-knowledge-intensive services & 50 & Wholesale/retail trade of motor vehicles \\
\hline & 351 & Building/repairing of ships and boats & & 51 & Wholesale trade \\
\hline & 15 & Food and beverages & & 52 & Retail trade \\
\hline & 16 & Tobacco & & 55 & Hotels and restaurants \\
\hline & 17 & Textiles & & 60 & Land transport \\
\hline & 18 & Clothing & & 63 & Supporting transport activities \\
\hline & 19 & Leather (products) & & 75 & Public administration, defense \\
\hline & 20 & Wood (products) & & 90 & Sewage and refuse disposal \\
\hline & 21 & Pulp, paper (products) & & 91 & Activities of membership organizations \\
\hline & 22 & Publishing and printing & & 93 & Other service activities \\
\hline & 36 & Furniture & & 95 & Activities of households \\
\hline & 23 & Coke, refined petroleum products & & 74 & Other business activities \\
\hline & 37 & Recycling & & 99 & Extraterritorial organizations and bodies \\
\hline \multirow[t]{3}{*}{ Other sectors } & 14 & Mining and Quarrying & & & \\
\hline & 40 & Electricity, gas, steam and hot water supply & & & \\
\hline & 45 & Construction & & & \\
\hline
\end{tabular}




\section{References}

Achcaoucaou, F., Miravitlles, P., \& León-Darder, F. (2014). Knowledge sharing and subsidiary R\&D mandate development: A matter of dual embeddedness. International Business Review, 23(1), 76-90.

Alcacer, J., \& Chung, W. (2011). Benefiting from location: Knowledge seeking. Global Strategy Journal, 1(1-2), 132-134.

Almeida, P., \& Kogut, B. (1997). The exploration of technological diversity and geographic localization in innovation: Start-up firms in the semiconductor industry. Small Business Economics, 9(1), 21-31.

Amara, N., \& Landry, R. (2005). Sources of information as determinants of novelty of innovation in manufacturing firms: Evidence from the 1999 statistics Canada innovation survey. Technovation, 25(3), 245-259.

Antonelli, C., \& Fassio, C. (2016). The role of external knowledge (s) in the introduction of product and process innovations. R\&D Management, 46(S3), 979-991.

Barba Navaretti, G., \& Venables, A. J. (2004). Multinational firms in the world economy. Princeton: Princeton University Press.

Bartlett, C. A., \& Ghoshal, S. (1986). Tap your subsidiaries for global reach. Harvard Business Review, 64(6), 87-94.

Beckman, C. M., Haunschild, P. R., \& Phillips, D. J. (2004). Friends or strangers? Firmspecific uncertainty, market uncertainty, and network partner selection. Organization Science, 15(3), 259-275.

Belderbos, R., Leten, B., \& Suzuki, S. (2017). Scientific research, firm heterogeneity, and foreign R\&D locations of multinational firms. Journal of Economics \& Management Strategy, 26(3), 691-711.

Belderbos, R., Carree, M., Diederen, B., Lokshin, B., \& Veugelers, R. (2004). Heterogeneity in R\&D cooperation strategies. International Journal of Industrial Organization, 22(8-9), 1237-1263.

Berghman, L., Matthyssens, P., \& Vandenbempt, K. (2012). Value innovation, deliberate learning mechanisms and information from supply chain partners. Industrial Marketing Management, 41(1), 27-39.

Berry, L. L., Shankar, V., Parish, J. T., Cadwallader, S., \& Dotzel, T. (2006). Creating new markets through service innovation. MIT Sloan Management Review, 47(2), 56.

Blomström, M., \& Kokko, A. (1998). Multinational corporations and spillovers. Journal of Economic Surveys, 12(3), 247-277.

Boehm, D. N., \& Hogan, T. (2013). Science-to-Business collaborations: A science-tobusiness marketing perspective on scientific knowledge commercialization. Industrial Marketing Management, 42(4), 564-579.

Bozeman, B. (2000). Technology transfer and public policy: A review of research and theory. Research Policy, 29(4), 627-655.

Brenner, B., \& Ambos, B. (2013). A question of legitimacy? A dynamic perspective on multinational firm control. Organization Science, 24(3), 773-795.

Brockhoff, K. (2003). Customers' perspectives of involvement in new product development. International Journal of Technology Management, 26(5-6), 464-481.

Brunswicker, S., \& Vanhaverbeke, W. (2015). Open innovation in small and medium-sized enterprises (SMEs): External knowledge sourcing strategies and internal organizational facilitators. Journal of Small Business Management, 53(4), 1241-1263.

Bureau van Dijk (2006). Belfirst database. Brussels: Bureau van Dijk Electronic Publishing.

Caloghirou, Y., Kastelli, I., \& Tsakanikas, A. (2004). Internal capabilities and external knowledge sources: complements or substitutes for innovative performance? Technovation, 24(1), 29-39.

Cantwell, J. (1989). Technology, innovation and multinational corporations. Oxford: Basil Blackwell.

Cantwell, J., \& Mudambi, R. (2005). MNE competence-creating subsidiary mandates. Strategic Management Journal, 26(12), 1109-1128.

Cantwell, J. A., \& Mudambi, R. (2011). Physical attraction and the geography of knowledge sourcing in multinational enterprises. Global Strategy Journal, 1(3-4), 206-232.

Cantwell, J., \& Piscitello, L. (2000). Accumulating technological competence: Its changing impact on corporate diversification and internationalization. Industrial and Corporate Change, 9(1), 21-51.

Cantwell, J., \& Smeets, R. (2013). FDI motives and host country productivity effects of US MNEs. In F. De Beule, \& Y. Nauwelaerts (Eds.). Innovation and creativity: Pillars of the future global economy (pp. 173-195). Cheltenham: Edward Elgar.

Cassiman, B., \& Golovko, E. (2011). Innovation and internationalization through exports. Journal of International Business Studies, 42(1), 56-75.

Cassiman, B., \& Veugelers, R. (2002). R\&D cooperation and spillovers: Some empirical evidence from Belgium. The American Economic Review, 92(4), 1169-1184.

Castellani, D., Montresor, S., Schubert, T., \& Vezzani, A. (2017). Multinationality, R\&D and productivity: Evidence from the top R\&D investors worldwide. International Business Review, 26(3), 405-416.

Castellani, D., \& Zanfei, A. (2006). Multinational firms, innovation and productivity. Cheltenham: Edward Elgar Publishing.

Chen, J., Chen, Y. F., \& Vanhaverbeke, W. (2011). The influence of scope, depth, and orientation of external technology sources on the innovative performance of Chinese firms. Technovation, 31(8), 362-373.

Chen, Y.-S., Lin, M. J. J., \& Chang, C. H. (2009). The positive effects of relationship learning and absorptive capacity on innovation performance and competitive ad vantage in industrial markets. Industrial Marketing Management, 38(2), 152-158.

Chen, Y., Vanhaverbeke, W., \& Du, J. (2016). The interaction between internal R\&D and different types of external knowledge sourcing: An empirical study of Chinese innovative firms. R\&D Management, 46(S3), 1006-1023.

Chesbrough, H. (2003). The logic of open innovation: Managing intellectual property. California Management Review, 45(3), 33-58.

Chung, W., \& Alcácer, J. (2002). Knowledge seeking and location choice of foreign direct investment in the United States. Management Science, 48(12), 1534-1554.

Cruz-González, J., López-Sáez, P., \& Navas-López, J. E. (2015). Absorbing knowledge from supply-chain, industry and science: The distinct moderating role of formal liaison devices on new product development and novelty. Industrial Marketing Management, 47(2), 75-85.

Dachs, B., \& Ebersberger, B. (2009). Does foreign ownership matter for the innovative activities of enterprises? International Economics and Economic Policy, 6(1), 41-57.

Dahlander, L., \& Gann, D. M. (2010). How open is innovation? Research Policy, 39(6), 699-709.

De Luca, L. M., \& Atuahene-Gima, K. (2007). Market knowledge dimensions and crossfunctional collaboration: Examining the different routes to product innovation performance. Journal of Marketing, 95-112.

Dörrenbächer, C., \& Gammelgaard, J. (2016). Subsidiary initiative taking in multinational corporations: The relationship between power and issue selling. Organization Studies, 37(9), 1249-1270.

Driffield, N., \& Love, J. H. (2007). Linking FDI motivation and host economy productivity effects: Conceptual and empirical analysis. Journal of International Business Studies, 38(3), 460-473.

Du, J., Leten, B., \& Vanhaverbeke, W. (2014). Managing open innovation projects with science-based and market-based partners. Research Policy, 43(5), 828-840.

Dunning, J. H. (2000). The eclectic paradigm as an envelope for economic and business theories of MNE activity. International Business Review, 9(2), 163-190.

Eisenhardt, K. M., \& Tabrizi, B. N. (1995). Accelerating adaptive processes: Product innovation in the global computer industry. Administrative Science Quarterly, 40, 84-110.

European Commission (2018). Science, research and innovation performance of the EU. Brussels: Directorate General for Research and Innovation.

European Commission (2012). Internationalisation of business investments in $R \& D$ and analysis of their economic impact. Luxembourg: Directorate General for Research and Innovation.

Fabrizio, K. R. (2009). Absorptive capacity and the search for innovation. Research Policy, $38(2), 255-267$.

Fang, C., Lee, J., \& Schilling, M. A. (2010). Balancing exploration and exploitation through structural design: The isolation of subgroups and organizational learning. Organization Science, 21(3), 625-642.

Feinberg, S. E., \& Gupta, A. K. (2004). Knowledge spillovers and the assignment of R\&D responsibilities to foreign subsidiaries. Strategic Management Journal, 25(8-9), 823-845.

Franke, N., \& Schreier, M. (2002). Entrepreneurial opportunities with toolkits for user innovation and design. The International Journal on Media Management, 4(4), $225-234$.

Freel, M. S. (2003). Sectoral patterns of small firm innovation, networking and proximity. Research Policy, 32(5), 751-770.

Frenz, M., \& Ietto-Gillies, G. (2009). The impact on innovation performance of different sources of knowledge: Evidence from the UK Community Innovation Survey. Research Policy, 38(7), 1125-1135.

Frost, T. S. (2001). The geographic sources of foreign subsidiaries' innovations. Strategic Management Journal, 22(2), 101-123.

Gassmann, O., Enkel, E., \& Chesbrough, H. (2010). The future of open innovation. R\&D Management, 40(3), 213-221.

Ghoshal, S., \& Bartlett, C. A. (1988). Creation, adoption, and diffusion of innovations by subsidiaries of multinational corporations. Journal of International Business Studies, 19(3), 365-388.

Greco, M., Grimaldi, M., \& Cricelli, L. (2016). An analysis of the open innovation effect on firm performance. European Management Journal, 34(5), 501-516.

Griffith, R., Harrison, R., \& Van Reenen, J. (2006). How special is the special relationship? Using the impact of US R\&D spillovers on UK firms as a test of technology sourcing. The American Economic Review, 96(5), 1859-1875.

Grimpe, C., \& Sofka, W. (2009). Search patterns and absorptive capacity: Low-andhightechnology sectors in European countries. Research Policy, 38(3), 495-506.

Gupta, A. K., Wilemon, D., \& Atuahene-Gima, K. (2000). Excelling in R\&D. ResearchTechnology Management, 43(3), 52-58.

Ha, Y. J., \& Giroud, A. (2015). Competence-creating subsidiaries and FDI technology spillovers. International Business Review, 24(4), 605-614.

Hemmert, M. (2004). The influence of institutional factors on the technology acquisition performance of high-tech firms: Survey results from Germany and Japan. Research Policy, 33(6-7), 1019-1039.

Hervas-Oliver, J. L., Sempere-Ripoll, F., \& Boronat-Moll, C. (2014). Process innovation strategy in SMEs, organizational innovation and performance: A misleading debate? Small Business Economics, 43(4), 873-886.

Hsu, C. W., Lien, Y. C., \& Chen, H. (2015). R\&D internationalization and innovation performance. International Business Review, 24(2), 187-195.

Huston, L., \& Sakkab, N. (2006). P\&G's new innovation model. An excerpt from connect and develop: Inside Procter \& Gamble's new model for innovation. Harvard Business Review, 84(3), 58-66.

Inkpen, A. C., \& Pien, W. (2006). An examination of collaboration and knowledge transfer: China-Singapore Suzhou Industrial Park. Journal of Management Studies, 43(4), 779-811.

Jarillo, J. C., \& Martínez, J. I. (1990). Different roles for subsidiaries: The case of mul tinational corporations in Spain. Strategic Management Journal, 11(7), 501-512.

Kappen, P. (2011). Competence-creating overlaps and subsidiary technological evolution in the multinational corporation. Research Policy, 40(5), 673-686.

Kessler, E. H., \& Chakrabarti, A. K. (1996). Innovation speed: A conceptual model of context, antecedents, and outcomes. The Academy of Management Review, 21(4), 1143-1191.

Knudsen, M. P., Tranekjer, T. L., \& Cantner, U. (2017). Open innovation in an 
international perspective: How to organize for (radical) product innovation. In A. Brem, \& E. Viardot (Eds.). Revolution of innovation management: Volume 2 internationalization and business models (pp. 15-40). London: Palgrave Macmillan.

Köhler, C., Laredo, P., \& Rammer, C. (2012). The impact and effectiveness of fiscal incentives for $R \& D$. Compendium on evidence of the effectiveness of innovation policy intervention. NESTA working paper No. 12/01. University of Manchester.

Kuemmerle, W. (1999). The drivers of foreign direct investment into research and development: An empirical investigation. Journal of International Business Studies, 30(1), $1-24$.

Lasagni, A. (2012). How can external relationships enhance innovation in SMEs? New evidence for Europe. Journal of Small Business Management, 50(2), 310-339.

Laursen, K., \& Salter, A. (2006). Open for innovation: The role of openness in explaining innovation performance among U.K. Manufacturing firms. Strategic Management Journal, 27(2), 131-150.

Le Bas, C., \& Sierra, C. (2002). 'Location versus home country advantages' in R\&D activities: Some further results on multinationals' locational strategies. Research Policy, 31(4), 589-609.

Ledwith, A., \& Coughlan, P. (2005). Splendid isolation: does networking really increase new product success? Creativity and Innovation Management, 14(4), 366-373.

Lee, C. Y., \& Huang, Y. C. (2012). Knowledge stock, ambidextrous learning, and firm performance: Evidence from technologically intensive industries. Management Decision, 50(6), 1096-1116.

Leiponen, A., \& Helfat, C. E. (2011). Location, decentralization, and knowledge sources for innovation. Organization Science, 22(3), 641-658.

Leten, B., Vanhaverbeke, W., Roijakkers, N., Clerix, A., \& Van Helleputte, J. (2013). IP models to orchestrate innovation ecosystems. California Management Review, 55(4), 51-64.

Lettl, C., Herstatt, C., \& Gemuenden, H. G. (2006). Users' contributions to radical innovation: Evidence from four cases in the field of medical equipment technology. R\& D Management, 36(3), 251-272.

Li, T., \& Calantone, R. J. (1998). The impact of market knowledge competence on new product advantage: Conceptualization and empirical examination. Journal of Marketing, 62(October), 13-29.

Lim, C., Hemmert, M., \& Kim, S. (2017). MNE subsidiary evolution from sales to innovation: Looking inside the black box. International Business Review, 26(1), 145-155.

Liu, X., Vahtera, P., Wang, C., Wang, J., \& Wei, Y. (2017). The delicate balance: Managing technology adoption and creation in multinational affiliates in an emerging economy. International Business Review, 26(3), 515-526.

Lööf, H., \& Heshmati, A. (2002). Knowledge capital and performance heterogeneity: A firm level innovation study. International Journal of Production Economics, 76(1), 61-85.

Makino, S., Lau, C. M., \& Yeh, R. S. (2002). Asset-exploitation versus asset-seeking: Implications for location choice of foreign direct investment from newly industrialized economies. Journal of International Business Studies, 33(3), 403-421.

March, J. G. (1991). Exploration and exploitation in organizational learning. Organization Science, 2(1), 71-87.

McMillan, G. S., Narin, F., \& Deeds, D. L. (2000). An analysis of the critical role of public science in innovation: The case of biotechnology. Research Policy, 29(1), 1-8.

Michailova, S., \& Zhan, W. (2015). Dynamic capabilities and innovation in MNC subsidiaries. Journal of World Business, 50(3), 576-583.

Miotti, L., \& Sachwald, F. (2003). Co-operative R\&D: Why and with whom? An integrated framework of analysis. Research Policy, 32(8), 1481-1499.

Monjon, S., \& Waelbroeck, P. (2003). Assessing spillovers from universities to firms: Evidence from French firm-level data. International Journal of Industrial Organization, 21(9), 1255-1270.

Moorman, C. (1995). Organizational market information processes: Cultural antecedents and new product outcomes. Journal of Marketing Research, 32(August), 318-335.

Murovec, N., \& Prodan, I. (2009). Absorptive capacity, its determinants, and influence on innovation output: Cross cultural validation of the structural model. Technovation, 29(12), 859-872.

Narula, R., \& Zanfei, A. (2005). Globalization of innovation. In J. Fagerberg, D. C. Mowery, \& R. R. Nelson (Eds.). The Oxford handbook of innovation (pp. 318-345). Oxford: Oxford University Press.

Nieto, M. J., \& Santamaría, L. (2007). The importance of diverse collaborative networks for the novelty of product innovation. Technovation, 27(6), 367-377.
Patel, P., \& Vega, M. (1999). Patterns of internationalisation of corporate technology: Location vs. Home country advantages. Research Policy, 28(2-3), 145-155.

Perez, M. P., \& Sánchez, A. M. (2003). The development of university spin-offs: Early dynamics of technology transfer and networking. Technovation, 23(10), 823-831.

Perkmann, M., \& Walsh, K. (2007). University-Industry relationships and open innovation: Towards a research agenda. International Journal of Management Reviews, 9(4), 259-280.

Rigby, D., \& Zook, C. (2002). Open-market innovation. Harvard Business Review, 80(10), 80-93.

Schmid, S., \& Schurig, A. (2003). The development of critical capabilities in foreign subsidiaries: Disentangling the role of the subsidiary's business network. International Business Review, 12(6), 755-782.

Schmid, S., Dzedek, L. R., \& Lehrer, M. (2014). From rocking the boat to wagging the dog: A literature review of subsidiary initiative research and integrative framework. Journal of International Management, 20(2), 201-218.

Sethi, R., Smith, D. C., \& Park, C. W. (2001). Cross-functional product development teams, creativity, and the innovativeness of new consumer products. Journal of Marketing Research, 38(1), 73-85.

Sofka, W., \& Grimpe, C. (2010). Specialized search and innovation performance-evidence across Europe. R\&D Management, 40(3), 310-323.

Strutzenberger, A., \& Ambos, T. C. (2014). Unravelling the subsidiary initiative process: A multilevel approach. International Journal of Management Reviews, 16(3), 314-339.

Teirlinck, P. (2005). Location and agglomeration of foreign R\&D activities in a small open economy. In P. Teirlinck, \& A. Spithoven (Eds.). Beyond borders: Internationalisation of $R \& D$ and policy implications for small Open economies (pp. 207-234). Amsterdam: Elsevier.

Tether, B. S. (2002). Who co-operates for innovation, and why: An empirical analysis. Research Policy, 31(6), 947-967.

Tether, B. S., \& Tajar, A. (2008). Beyond industry-University links: Sourcing knowledge for innovation from consultants, private research organisations and the public science-base. Research Policy, 37(6), 1079-1095.

Tödtling, F., Lehner, P., \& Kaufmann, A. (2009). Do different types of innovation rely on specific kinds of knowledge interactions? Technovation, 29(1), 59-71.

Tsai, K. H. (2009). Collaborative networks and product innovation performance: Toward a contingency perspective. Research Policy, 38(5), 765-778.

Tsai, K.-H., \& Hsieh, M.-H. (2009). How different types of partners influence innovative product sales: Does technological capacity matter? Journal of Business Research, 62(12), 1321-1328.

Tsai, K. H., \& Wang, J. C. (2009). External technology sourcing and innovation performance in LMT sectors: An analysis based on the Taiwanese Technological Innovation Survey. Research Policy, 38(3), 518-526.

UNCTAD (2005). Transnational corporations and the internationalization of R\&D. United Nations Conference on Trade and Development.

Vega-Jurado, J., Gutiérrez-Gracia, A., Fernández-de-Lucio, I., \& Manjarrés-Henríquez, L. (2008). The effect of external and internal factors on firms' product innovation. Research Policy, 37(4), 616-632.

Veugelers, R., \& Cassiman, B. (2004). Foreign subsidiaries as a channel of international technology diffusion: Some direct firm level evidence from Belgium. European Economic Review, 48(2), 455-476.

Villena, V. H., Revilla, E., \& Choi, T. Y. (2011). The dark side of buyer-Supplier relationships: A social capital perspective. Journal of Operations Management, 29(6), 561-576.

Von Hippel, E., \& Katz, R. (2002). Shifting innovation to users via toolkits. Management Science, 48(7), 821-833.

Vuola, O., \& Hameri, A. P. (2006). Mutually benefiting joint innovation process between industry and big-science. Technovation, 26(1), 3-12.

Zaheer, S., \& Nachum, L. (2011). Sense of place: From location resources to MNE locational capital. Global Strategy Journal, 1(1-2), 96-108.

Zhang, J., Hoenig, S., Di Benedetto, C. A., Lancioni, R. A., \& Phatak, A. V. (2009). What contributes to the enhanced use of customer, competition and technology knowledge for product innovation performance? A survey of multinational companies' subsidiaries operating in China. Industrial Marketing Management, 38(2), 207-218.

Zhang, F., Jiang, G., \& Cantwell, J. A. (2015). Subsidiary exploration and the innovative performance of large multinational corporations. International Business Review, 24(2), 224-234. 